\title{
ТЕКСТУАЛНА КОХЕРЕНТНОСТ И КОХЕЗИЈА У РАДОВИМА СТУДЕНАТА ПРВЕ И ТРЕЋЕ ГОДИНЕ СТУДИЈА ГЕРМАНИСТИКЕ ${ }^{1}$
}

Циљ анализе представља испитивање присутности кохезивних средстава у текстовима студената и одређивање нивоа њихове текстуалне компетенције на основу критеријума кохерентности. За потребе истраживања спроведена је корпусна анализа писмених испита студената прве и треће године студија германистике на Филолошком факултету Универзитета у Београду у академској 2018/19. години. Резултати анализе показују да текстуална језичка компетенција студената на првој години одговара Б1 нивоу Заједничког европског оквира, док је иста компетенција код студената треће године на нивоу Ц1.1. На основу добијених резултата закључује се да разлика у нивоима текстуалне језичке компетенције између прве и треће године износи скоро цела два нивоа.

Кључне речи: текстуална језичка компетенција, језичка компетенција, кохерентност, кохезија, Заједнички европски оквир

\section{Увод}

Честа суоченост са страном културом и страним језиком у епохи транскултурности довела је до тога да се познавање страних језика препозна као једна од кључних вештина коју је неопходно поседовати. Доказ у прилог томе представља и званични документ Савета Европе о кључним компетенцијама за

* danijella95@gmail.com

1 Овај чланак представља, уз одређене измене, део истоименог мастер рада ауторке. 
целоживотно учење, где се комуникација на матерњем језику препознаје као најважнија компетенција, а одмах иза ње следи способност комуникације на страном језику ${ }^{2}$.

Оваква неопходност комуницирања на страном језику имала је последице и по развој дидактике и методике наставе страних језика, које се пре свега огледају у све већој популарности и заступљености комуникативног, а нешто касније и посткомуникативног приступа у настави страних језика. Комуникативни приступ у средиште пажње поставио је функционалну страну језика, односно његову употребу у свакодневним животним ситуацијама (попут куповине у продавници, одласка код лекара, активности у слободно време и сл), те се у уџбеничкој литератури и настави страних језика инсистира на оспособљавању појединца за сналажење у оваквим и сличним ситуацијама. Као последица овога, у настави страних језика примећује се превласт усменог изражавања, док су остале три компоненте језика - вештина слушања, вештина разумевања текстова, а посебно вештина писања и састављања текстова на страном језику - занемариване. У настојању да се и другим језичким вештинама посвети заслужена пажња, овај рад је посвећен анализи последње поменуте вештине, текстуалној компетенцији, односно аспектима кохерентности и кохезије текста.

\section{Кохезија и кохерентност текста}

Један од основних задатака лингвистике текста, научне дисциплине чији је текст основни предмтет интересовања, састоји се у томе да опише и класификује елементе којима се остварује повезаност у тексту, односно елементе који текст чине кохерентним - другим речима, елементе који текст чине текстом. Кохерентност је стога један од централних појмова у оквиру ове дисциплине, под којим се, у најширем смислу, подразумевају „раз-

2 Доступно на веб страници: https://eur-lex.europa.eu/legal-content/EN/ TXT/PDF/?uri=CELEX:52018SC0014\&from=EN, приступљено 17.01.2020. 
личите димензије повезаности текста“ (Шварц-Фризел и Констен 2014: 74). Будући да су ове димензије врло комплексне, не треба да чуди то што различити аутори појам кохерентности различито широко схватају и дефинишу. Тако Бринкер (1988: 20) разликује две врсте кохерентности: граматичку, која се односи на синтаксичко-семантичке везе између реченица, и тематску кохерентност, односно когнитивну повезаност текста постигнуту јединственошћу теме. На овај начин аутор под појмом кохерентности обједињује све експлицитне и имплицитне везе између елемената текста. Сличан приступ препознаје се и код Халидеја и Хасана. Ова два аутора под појмом кохезије подразумевају „везе између значења која постоје унутар текста и одређују га као текст“ (Халидеј, Хасан 1976: 4), чиме наглашавају семантички аспект овог појма. Ово виђење одговарало би тематској кохерентности код Бринкера. Са друге стране, оно што Бринкер (1988: 21) назива граматичком кохерентношћу, Халидеј и Хасан (1976: 3) називају „кохезивним везама”, односно засебним јединицама кохезије.

У контрасту са оваквим схватањем везивних елемената у тексту стоји становиште де Богранда и Дреслера (1981), који праве јасну разлику између кохерентности и кохезије и ова два појма сматрају основним критеријумима текстуалности. Њихов појам кохезије преклапа се са граматичком кохерентношћу код Бринкера, док се кохерентност код њих односи искључиво на логичко-садржинску повезаност текста. Разликовању између појмова кохерентности и кохезије приклања се и Барбара Зандиг, дефинишући кохезију као „експлицитну језичку повезаност израза у тексту у складну секвенцу“3, док под кохерентношћу сматра „ширу смисаону повезаност која се конструише на основу текста и знања о језику и свету које реципијент поседује“4 (Зандиг 2006: 363). У том смислу кохерентност представља субјективни когнитивни процес пре него особи-

3 „Kohäsion ist die explizite sprachliche Verknüpfung von Äußerungen in einem Text zu einer zusammengehörigen Sequenz". Уколико није другачије назначено, све наводе са страних језика превела Д. В.

4 „Kohärenz ist der größere Sinnzusammenhang, der anhand des Textes und anhand des Sprach- und Weltwissens von den Rezipierenden zu konstruieren ist." 
ну самог текста, и зависи искључиво од тога да ли реципијент располаже наведеним знањима, као и од тога да ли ће их у датом тренутку активирати (уп. Шварц-Фризел 2006: 64).

Будући да је граница између појмова кохезије и кохерентности прилично нејасна и да различити аутори ове појмове схватају различито широко, за потребе анализе везивна средства ћемо посматрати као јединствену групу обухваћену називом „средства за постизање кохерентности и кохезије“. Сходно томе, и термине кохезија и кохерентност ћемо користити као јединствени критеријум.

\section{Средства за постизање кохерентности и кохезије текста}

Да би неки текст за нас имао смисао, односно да би нам био разумљив и самим тим користан, његове реченице морају на неки начин бити повезане једна са другом у складну целину. На тај начин сваку реченицу можемо интерпретирати на основу реченица које јој претходе и, корак по корак, открити поруку коју аутор текста жели да нам пренесе. Да би могле да испуне своју комуникативну функцију, те реченице свакако морају бити (1) граматички коректне, (2) смислено повезане тако да се надовезују једна на другу, и (3) тематски повезане. Овим су обухваћени и основни, најшире схваћени критеријуми текстуалности: кохерентност и кохезија. Иако не представљају довољан услов да би се нека језичка датост сматрала текстом, кохерентност и кохезија су критеријуми без којих текст не може да постоји.

Најуже схватање кохезије подразумева да кохерентност неког текста произлази из његове садржајно-тематске јединствености (Адамзик 2016: 251f.). Испуњење овог критеријума могуће је на тај начин што се на предмет расправе у тексту указује више пута. Овај текстуални феномен поновног указивања на нешто што је у тексту већ споменуто, Бринкер (1988) назива управо поновним указивањем на дати појам (нем. Wiederaufnahme), Лангер (1995) испреплетеношћу (нем. 
Verflochtenheit), а Линке, Нусбаумер (2000) рекурентношћу (нем. Rekurrenz).

Средства рекурентности узета у обзир у оквиру овог истраживања могу се поделити у три велике групе: рекурентност или поновно указивање, одређени и неодређени члан, и конексија.

На једном споменути објекат може се указивати различитим језичким средствима (што је и пожељно, како би се избегло да текст делује монотоно). Тако се рекурентност може постићи уз помоћ истог језичког материјала (У нашој улици живи један дечак. Дечак је врло несташан.), различитог језичког материјала (То дериште треба научити памети.), или уз помоћ замене (супституције) (Он ми је једанпут лоптом разбио прозор.) (уп. Линке, Нусбаумер 2000: 306). Из датих примера лако се закључује да рекурентност претпоставља да се референтни исказ односи на исти ванјезички објекат као и исказ искоришћен за поновно указивање на њега (Бринкер 1988: 26). Оваква појава да се више различитих исказа односи на исти референтни појам у ванјезичкој стварности, назива се кореферентност. Битно је нагласити да појам кореферентности не треба мешати са појмом синонимије, која представља чисто семантички феномен, иако синоними могу бити средство за изражавање кореферентности ( уп. Шварц-Фризел, Констен 2014: 81).

Према Линке и Нусбаумер (2000: 307ff., цит. према Зандиг 2006: 367) могу се разликовати три врсте рекурентности у тексту: (1) чисто изразна, (2) чисто садржајна и (3) и изразна и садржајна. С обзиром на то да се чисто изразна рекурентност односи првенствено на изразни ниво текста и подразумева пре свега нпр. ритам, риму или стилске фигуре попут алитерације или паралелизма, она није била заступљена у текстовима студената; од највеће важности за испитивање нивоа текстуалне језичке компетенције студената била је комбинација изразне и садржајне рекурентности.

Под комбинацијом изразне и садржајне рекурентности подразумева се рекурентност језичког материјала, која се може појавити у виду рекурентности истоветног језичког материјала, парцијалне рекурентности или супституције уз помоћ, на пример, синонима или хиперонима. У ову врсту рекурентности 
спадају, осим тога, и парафраза и проформе, док се у садржајну рекурентност убрајају рекурентност имплицитног, рекурентност семантичких обележја и рекурентност тематског оквира (од којих се само последњи показао као битан за анализу).

Када су у питању одређени и неодређени члан, њихова употреба као кохезивног средства уско је повезана са рекурентношћу идентичног језичког материјала. Наиме, при увођењу референтног објекта као нове информације, у немачком језику (као и у неким другим језицима који познају граматичку категорију одређеног и неодређеног члана) користи се неодређени члан, док се при поновном реферисању на исти појам употребљава одређени члан. Употреба одређеног и неодређеног члана, односно грешке ове природе, од значаја су за кохерентност текста утолико што погрешна употреба или изостављање члана може довести до потешкоћа у интерпретацији текста и самим тим до оцењивања текста као некохерентног.

Трећи тип кохезивних средстава представљају конектори. Прототип конектора у немачком језику чине конјунктори и субјунктори, међутим, везе између реченица могу се изразити и другим језичким средствима, попут номиналних, прилошких и препозиционалних фраза, прилога, придева итд.

На основу значења, конектори се деле на: копулативне, адверзативне, дисјунктивне, каузалне, консекутивне, финалне, концесивне, кондиционалне, темпоралне, рестриктивне, спецификујуће, компаративне, пропорционалне, модално-инструменталне и неутралне конекторе (Ђуровић 2011: 190f.)

\section{Когнитивни аспекти кохерентности текста}

Познато је да свака реч, па и реченица, са собом носи неко значење. Међутим, исто толико је важно и запитати се: да ли след тих реченица као реципијента има неки смисао? На који начин је тај смисао репрезентован? Изрази споменути у тексту могу, засебно, имати многа значења; у датом тексту, међутим, они имају само један смисао (уп. де Богранд и Дреслер 1981: 53). Када говоримо о смислу, говоримо о дубљој структури 
текста, односно о ономе што де Богранд и Дреслер (1981) називају кохерентношћу (за разлику од њиховог схватања кохезије као граматичких везивних елемената), а ван Дајк (1992) глобалном кохерентношћу или макроструктуром.

Да би се открио смисао неког текста није довољно само језичко знање, односно познавање одређеног комуникацијског кода, већ је потребно и опште знање, знање о свету око нас, као и одређене когнитивне способности. Како наводе де Богранд и Дреслер (1981:54), одређени изрази са којима се сусрећемо у тексту у нашој глави активирају увек исте концепте, тј. 'конфигурације знања' везане за тај израз, који су смештени у нашој 'активној меморији'. Концепти који се активирају углавном су исти код свих реципијената, на основу чега се може закључити да се овако схваћена кохеретност не конституише на индивидуалном нивоу, већ прати одређене опште стандарде. Уз помоћ ових когнитивних способности, способни смо да различите пропозиције у тексту доведемо у везу једну са другом, при чему несвесно упоређујемо текстуалну реалност са сопственом, свакодневном реалношћу (уп. Шварц-Фризел, Констен 2014: 90). Шварц-Фризел и Констен такође напомињу да препознавање континуитета у неком тексту не зависи само од следа граматички коректно везаних реченица, већ и од препознавања плаузибилних веза између тих реченица. Ову појаву називају критеријумом плаузибилности (ibid. 89). Плаузибилност реципијенту постаје видљива тек након активирања одговарајућих концепата, односно 'чанкова' ${ }^{5}$ знања.

Будући део дубље структуре текста, ови аспекти кохерентности односно кохезије не могу се посматрати у самом тексту, јер не представљају видљив, 'опипљив' језички материјал. За предмет овог истраживања когнитивни аспекти кохерентности текста од важности су превасходно при одређивању критеријума за евалуацију елемената кохерентности и кохезије у писменим радовима студената.

5 Термин 'чанк' (енг. chunk), у психологији означава речи или појмове груписане у јединствену целину ради лакшег процесуирања. 


\section{Методологија истраживања}

За анализу су коришћени писмени радови студената прве и треће године студија из предмета Савремени немачки језик, на смеру Немачки језик, књижевност, култура на Филолошком факултету у Београду, и то радови из трећег и четвртог испитног рока школске 2018/2019. године. Ради се о следећим врстама текста:

1) Писмо жалбе - трећи испитни рок на првој години студија;

2) Опис графикона - четврти испитни рок на првој години студија;

3) Аргументација и изражавање мишљења на основу задатог текста - трећи и четврти испитни рок на трећој години студија.

Будући да се ради о два узастопна испитна рока, међу радовима у четвртом испитном року присутни су и поновљени радови студената који у трећем испитном року на овом испиту нису задовољили критеријуме. Ради равноправности радова, у овој ситуацији ограничили смо се само на прве написане радове студената. Након елиминације поновљених радова студената, корпус за анализу су чинила:

- 42 рада из трећег и 13 радова из четвртог испитног рока на првој години студија (укупно 55 радова), и

- 34 рада из трећег и пет радова из четвртог испитног рока на трећој години студија (укупно 39 радова).

У погледу радова студената са прве и треће године студија, прво што упада у очи јесте да се суочавамо са три различите текстуалне форме (писмо жалбе, опис графикона, аргументација и изношење мишљења). На први поглед ово може деловати као методолошки проблем, будући да различите врсте текста захтевају различита језичка средства, но у овом случају све три врсте текста захтевале су и аргументовање и изражавање сопственог мишљења о датој теми. Стога можемо поћи од тога да би за конституисање ових врста текста била потребна врло слична језичка средства.

Друга препрека са којом смо се суочили јесте чињеница да се број захтеваних речи разликује за прву и за трећу годину (у првој години текст треба да садржи око 200 речи, док за трећу 
годину ова бројка износи 250-280 речи). Овај проблем решили смо на следећи начин: на основу задатог броја речи (за трећу годину узета је средња вредност од 265 речи) израчунали просечан број речи у свим текстовима са прве (11.000 речи), односно са треће године (10.335 речи), како бисмо на крају могли да одредимо процентуалну присутност кохезивних средстава у текстовима у односу на укупан број речи. Такође смо израчунали процентуалну присутност две велике групе кохезивних средстава - конектора и средстава рекурентности.

У даљем тексту ће бити изложени најважнији резултати спроведене анализе.

\section{Рекурентност језичког материјала}

Када је у питању рекурентност језичког материјала, резултати анализе изгледају овако:

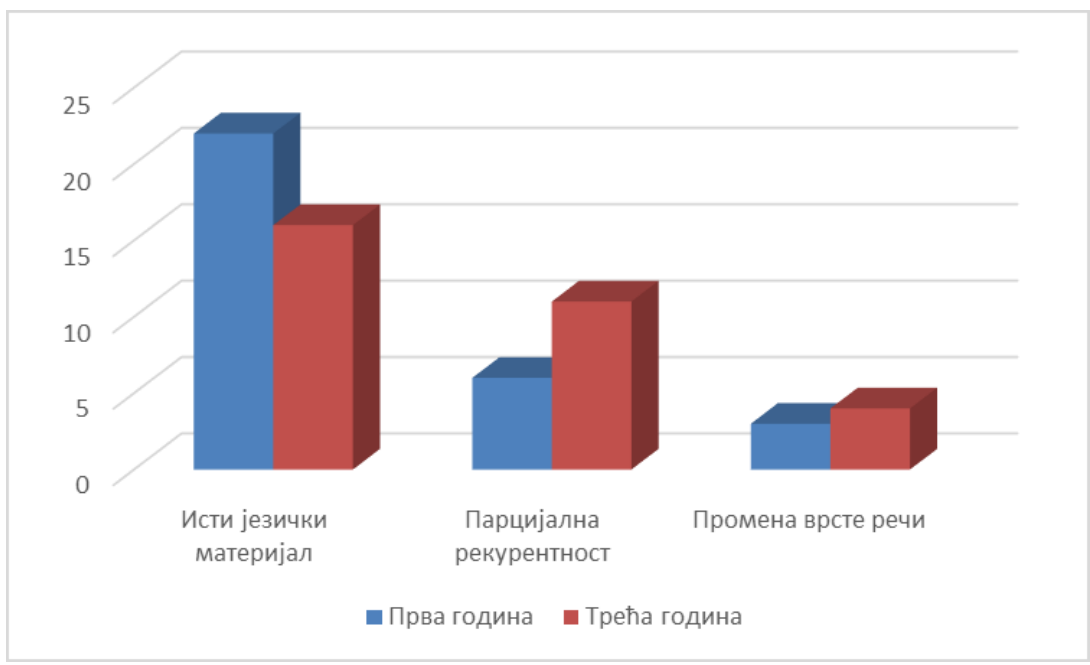

На основу графикона можемо приметити знатно већу употребу истоветног језичког материјала у радовима студената са прве године студија, док је на трећој години нешто заступлље- 
нија парцијална рекурентност и промена врсте речи. Овакви резултати говоре у прилог томе да студенти треће године располажу ширим вокабуларом, што им омогућава да за указивање на претходно споменути референтни објекат користе разноврснији језички материјал. Ова тврдња потврђује се и при анализи супституционих средстава:

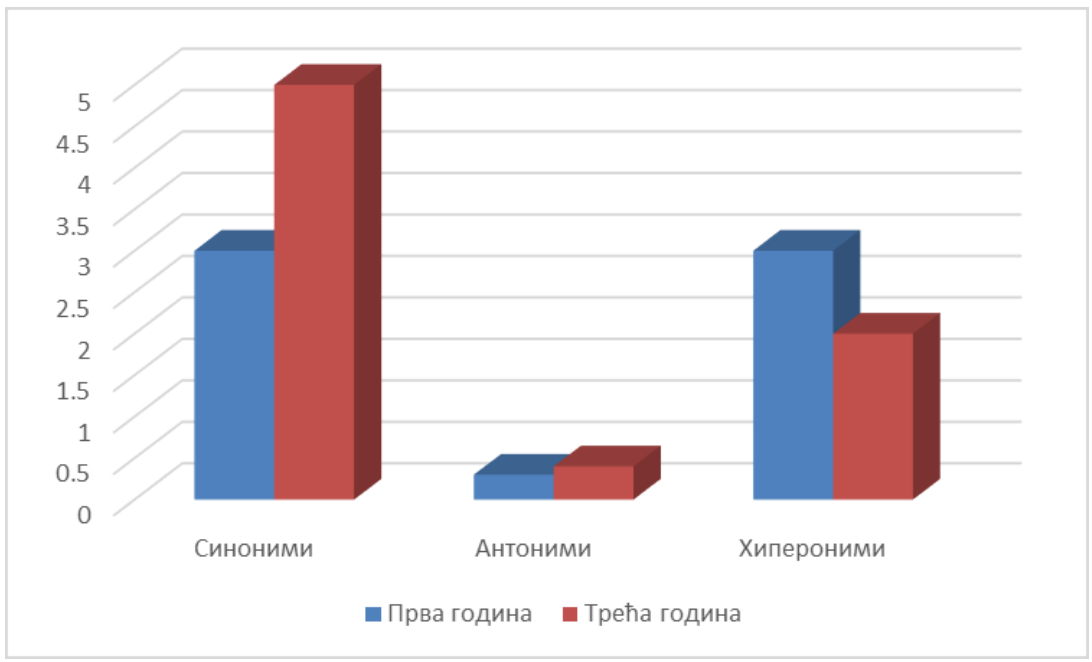

Поред тога што је супституција уопштено чешћа појава у радовима студената са треће године, у њиховим радовима се може приметити и знатно интензивнија употреба синонима за поновно указивање на споменути појам. Објашњење за већу бројност хиперонима на првој години могло би да лежи у чињеници да су хипероними, као општији појмови, често лексеме које се јављају на нижим нивоима учења страног језика, те су из тог разлога познатији студентима на нижим годинама, док синоними понекад могу захтевати врло висок ниво језичке компетенције, до ког се долази тек на каснијим годинама студија.

Антоними су, међутим, и на првој и на трећој години везани за лексеме које припадају нижим нивоима језичког знања (bestehen - durchfallen, viel Zeit - wenig Zeit, schließen - öffnen) и најчешће се не заснивају на лексемама добијеним уз помоћ 
механизама творбе речи (префиксацијом или суфиксацијом), већ на тзв. правим антонимима, односно антонимима са различитим кореном речи. Разлог томе лежи у чињеници да често постоји несигурност око тога уз помоћ које морфеме се гради одређени антоним. Будући да је творба речи део градива на трећој години студија, разумљиво је да ова област представља потешкоћу за студенте прве године, али и извор несигурности за студенте треће године, због чега је већина студената компензује уз помоћ других језичких средстава (попут негације).

\section{Проформе}

Док супституција представља замену референтног израза изразом који сам за себе има одређену семантичку вредност, дотле проформе представљају замену референтног израза (најчешће кратким) речима које су значењски 'празне', односно имају само способност да се путем граматичких категорија (рода, броја) везују за друге речи или изразе. Прототип проформи стога јесу заменице, али као средство анафоризације могу бити употребљени и прилози (ту, овде, тамо), заменички прилози (нем. Pronominaladverbien - worüber, dabei, damit), присвојни детерминативи (наш, мој, њен) као и демонстративне заменице (oвај, тај, онај). Већина проформи је, будући значењски 'празне', везана за граматички (синтаксички) аспект много више него за семантички (мада, наравно, границе између различитих аспеката језика нису увек јасне и прецизне). Немајући своје самостално значење, ове речи се строгим синтаксичким и семантичким правилима везују за референтни израз, што их чини знатно компликованијим за употребу. Поред тога (или управо због тога), многе проформе, попут нпр. заменичких прилога, уче се тек на напреднијим нивоима језичке компетенције, будући да је потребно неко време да би се схватиле семантичке везе које се успостављају уз њихову помоћ. Ово, вероватно, представља и разлог за то што је заступљеност већине проформи већа на трећој години студија.

У текстовима студената јавља се укупно једанаест врста анафоричких елемената. У односу на укупан број средстава ре- 
курентности, проформе у текстовима са прве године студија чине 60\%, док овај број за трећу годину износи 61\%. Квантитативно гледано, ово није велика разлика. Највећа дискрепанца, међутим, може се уочити у квалитету, односно разноликости одабраних језичких средстава анафоризације:

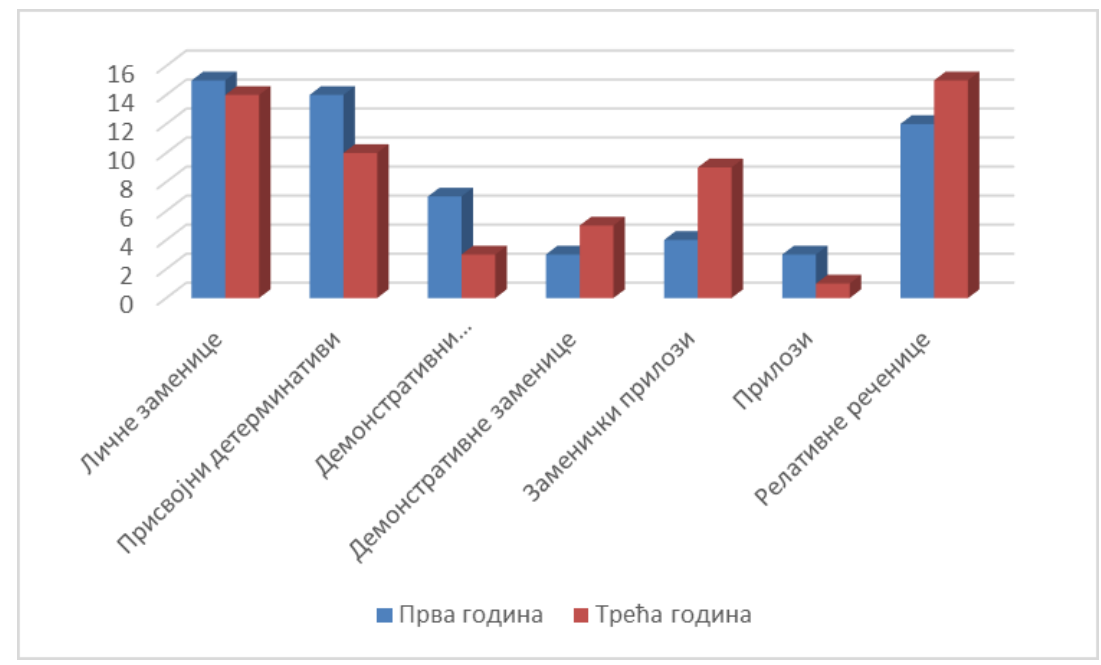

Како резултати показују, проформе које су знатно бројније у радовима са прве године јесу личне заменице, присвојни придеви и демонстративни детерминативи. Са једне стране, личне заменице и присвојни детерминативи су речи које се уче већ на самом почетку, тако да њихова већа бројност сведочи о томе да се студенти прве године више ослањају на познате и стога сигурне конструкције, док студенти треће године поред ових врста речи употребљавају и многа друга језичка средства. Са друге стране, чешћа употреба демонстративних детерминатива на првој години може се образложити чињеницом да су многи студенти прве године, с обзиром на тему жалбе, већ у првој реченици користили формулацију 'на овом факултету/ на овој катедри', иако дати референтни објекат није био претходно споменут, али се имплицитно подразумевао. 
Насупрот томе, на трећој години се примећује чешћа употреба демонстративних заменица и заменичких прилога. Ово не изненађује уколико се узме у обзир да демонстративне заменице захтевају нешто већу способност апстраховања и схватања семантичких веза него демонстративни детерминативи, већ самим тим што употреба демонстративних детерминатива у већини случајева иде у пару са рекурентношћу истог језичког материјала, док употреба демонстративних заменица захтева вишу језичку компетенцију која кориснику омогућава да препозна имплицитне семантичке везе између израза на вишем нивоу од реченичког. Заменички прилози, са друге стране, претпостављају и одређено синтаксичко знање, будући да један њихов део чини препозција која директно зависи од валентности лексеме за коју се везује. Несигурност студената у вези са препозицијом која одговара датој лексеми може стога бити један од разлога мање заступљености овог кохезивног средства у радовима студената са прве године студија.

Већа присутност релативних реченица, заједно са већим процентуалним уделом демонстративних заменица у радовима студената са треће године студија доприноси већој заступљености укупних зависних реченица на трећој години студија, што ће се додатно потврдити и анализом конектора (субјунктора). Присутност већег броја зависних реченица говори у прилог чињеници да студенти на трећој години студија раполажу разноврснијим и комплекснијим језичким материјалом, те је њихова језичка компетенција, глобално гледано, на вишем нивоу него код студената на првој години студија.

\section{Конектори}

Као што је раније већ напоменуто, конектори јесу речи којима се изражава семантичка повезаност две или више реченица, чиме у највећем броју случајева као резултат од неколико простих реченица настаје једна сложена. (Изузетак постоји у оним случајевима када као конектори нису употребљене конјункције, већ нека друга врста речи; међутим, комплекс- 
ност следа реченица који настаје на овај начин може се изједначити са комплексношћу сложених реченица насталим уз помоћ конјункција.) Тако настале сложене реченице јесу одлика вишег нивоа језичке компетенције, управо због тога што подразумевају већу способност апстраховања и (ре)конструисања семантичких веза у тексту.

Из овог разлога било би оправдано претпоставити да ће заступљеност конектора бити већа у радовима студената са треће године студија, што се и показало тачним: У односу на просечан укупан број речи у текстовима, разлика у процентуалној заступљености конектора износи готово два процента у корист треће године (8,2\% напрема 6,4\%). Ова бројка можда на први поглед не делује значајно, али, као и код рекурентности, највећа разлика може се приметити управо у разноврсности употребљених конектора.

Када је реч о копулативним конекторима, с обзиром на њихову семантику очекивано је да они представљају најбројнију заступљену групу конектора у текстовима (чак $37 \%$ свих конектора на првој и 40\% на трећој години). Учесталост различитих копулативних конектора изгледа овако:

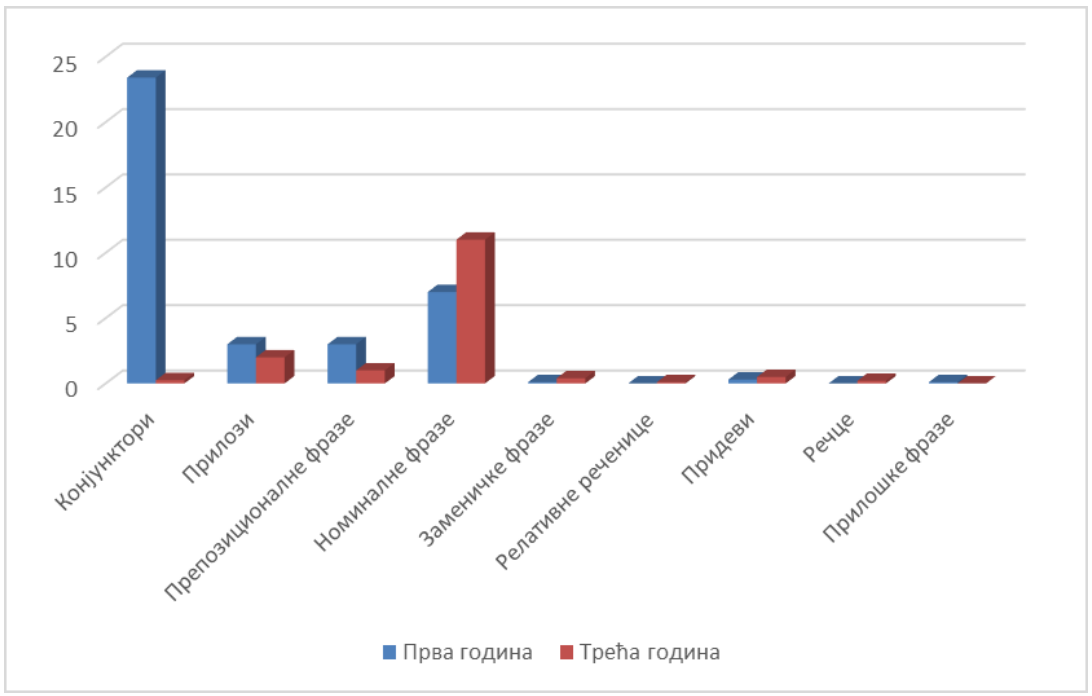


Убедљиво најчешће заступљену групу копулативних конектора чине конјунктори (преко 60\% од свих копулативних конектора на обе године), што не чуди када се узме у обзир чињеница да првенствено саставни конектор 'u' (und) генерално представља један од најучесталијих везника. (Он је у свим текстовима и на првој и на трећој години, поред конектора dass, најзаступљенији конектор, са преко 130 рекуренција.) Такође, на трећој години се може посматрати и већа присутност дводелних копулативних конјунктора (nicht nur... sondern auch, sowohl... als auch) - док је на првој години употребљен само један овакав конектор, на трећој години их је употербљено девет. Треба, међутим, још једном напоменути да се ради само о конекторима који повезују реченице; уколико би се узеле у обзир и номиналне фразе повезане дводелним конекторима, њихова присутност на обе године била би знатно виша.

На другом месту по заступљености јесу номиналне фразе, са знатно већом заступљеношћу на трећој години (разлика од $3 \%$ ). Како се у овим случајевима ради о фразама попут на првом месту, први/други/следећи разлог/аргумент, на последњем месту $^{6}$ и сл, јасно је да ове фразе првенствено служе за структурисање текста. С обзиром на то да се ради о набрајању, одлучили смо да и ове фразе уврстимо у набрајајуће копулативне конекторе. Тако смо делимично добили увид и у способност студената да на јасан и логичан начин структуришу текст, што такође знатно доприноси кохерентности текста. На основу добијених података приказаних у горњој табели може се, стога, закључити да студенти треће године, користећи се већим бројем ових и сличних фраза, на бољи начин структуришу своје текстове, због чега се у њима лакше може испратити 'црвена нит' од почетка до краја текста. У текстовима са прве године недостатак ових конектора најчешће је надомештен копулативним конјункторима, због чега се понекад стиче утисак монотоности текста. Поред тога, на првој години у ову сврху коришћени су и прилози попут erstens, zweitens, drittens, или препозиционалне фразе

6 Нем. An erster/letzter Stelle, der erste/zweite/nächte Grund, das erste/zweite/nächste Argument. 
попут auf dem ersten/zweiten/dritten Platz, мада ни збир свих копулативних номиналних и препозционалних фраза и прилога искоришћених у радовима на првој години не надмашује укупан број искоришћених копулативних номиналних фраза у радовима на трећој години (90 према 91). При томе треба такође узети у обзир да је укупан број речи у текстовима треће године мањи од укупног броја речи на првој години.

Из графичког приказа може се закључити да су ове четири врсте речи у функцији копулативних конектора готово једине присутне на првој години, док се у овој функцији на трећој години јављају још и заменичке фразе, једна релативна реченица (Was noch zu erwähnen wäre, ist...) и придеви, што говори у прилог већој разноврсности конектора на трећој години.

Каузални конектори чине трећу групу конектора по учесталости, одмах након копулативних и неутралних конектора. Када је реч о њиховој заступљености у анализираним текстовима, такође се може приметити да је њихов удео у радовима студената са треће године знатно већи него на првој години, као и да је језички материјал коришћен за изражавање каузалних релација разноврснији на трећој години. Графички приказ добијених резултата изгледа овако:

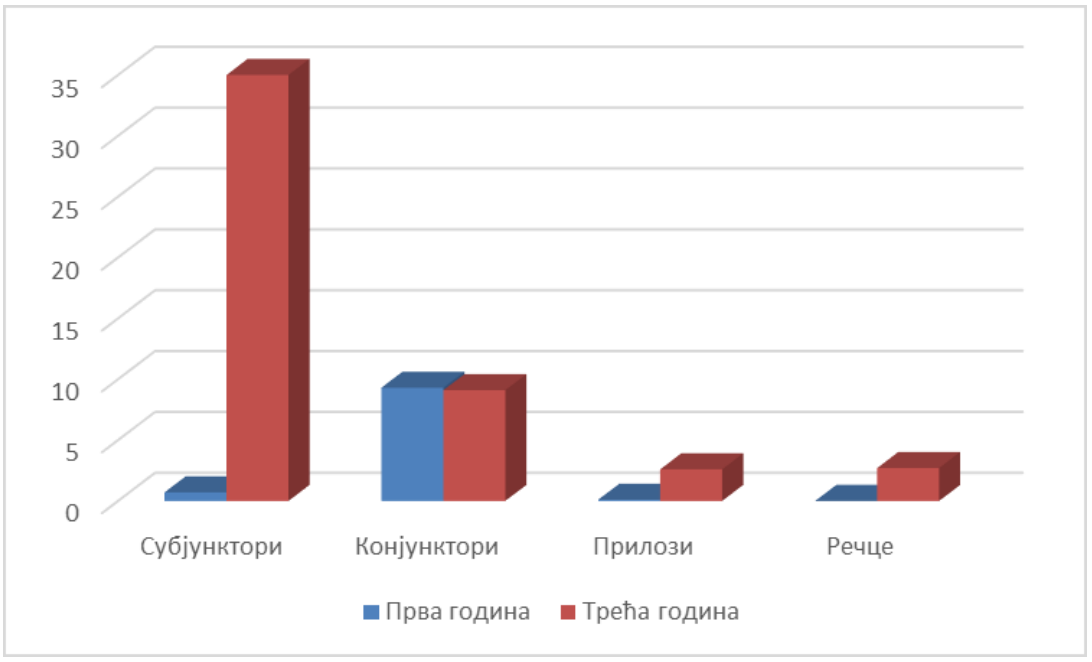


Оно што на први поглед упада у очи јесте разлика у употреби конјунктора која износи готово 35\% (у односу на укупан број каузалних конектора). Разлог томе може се потражити у чињеници да прототип каузалних конектора јесу субјунктори weil и $d a$, док је конјунктор denn нешто ређе у употреби. Узимајући то у обзир, иако је присуство каузалних конектора свакако веће у радовима са треће године, и то за око 3\%, употреба субјунктора је скоро изједначена, а учесталост прилога и речци у овој функцији нешто већа на трећој години, може се доћи до закључка да студенти на трећој години користе више врста каузалних конектора како би избегли да текст одаје утисак једноличности, док се студенти прве године више држе учесталије и стога сигурније варијанте, односно субјунктора.

\section{Когнитивни аспекти кохерентности текста}

Когнитивни аспекти кохерентности пре свега се односе на читаочеву интерпретацију текста. У овом делу ћемо изнети општи утисак при читању сваке врсте текста и факторе који су на њега утицали.

Када је реч о писмима жалбе на првој години, прво што се може приметити јесте да скоро сви текстови од почетка до краја имају јасну структуру - обраћање, увод, главни део и завршни део. Копулативне номиналне фразе такође доприносе организацији текста, тако да читалац у тексту може добро да се оријентише. Међутим, оно што упада у очи при читању ових текстова јесте чињеница да скоро сви радови почињу и завршавају се на исти начин, односно да студенти за уводни и завршни део писме користе готово идентичне фразе. Са једне стране, дате фразе је свакако пожељно користити како би текст имао јасну структуру, међутим, са друге стране, посебно код употребе фраза попут Ich wende mich an Sie/schreibe Ihnen mit einer Beschwerde; Ich glaube, Sie verstehen, wie enttäuscht ich bin или Ich sehe mich gezwungen, meinen Anwalt einzuschalten готово да нема никаквих одступања или измена, чак и када оне (посебно ова последња) у датом кон- 
тексту немају много смисла. Ова појава говори о могућности да су студенти једноставно напамет научили фразе које су им понуђене као алат, како би их само 'залепили' у текст на одговарајуће место. Због тога читалац понекад мора да се замисли над одређеним деловима текста како би одгонетнуо смисао, што доприноси утиску некохерентности текста.

Слична тенденција може се препознати и при описивању графикона. Наиме, премда сви текстови имају јасну структуру, та структура је у овом случају предодређена питањима постављеним у самом задатку, на која је у оквиру текста требало одговорити. Проблем који се у вези са тим јавља јесте честа неспособност студената да повежу одговоре на задата питања у јединствену целину уз помоћ средстава за постизање кохерентности, тако да садржај од почетка до краја прати одређену тематику и на основу тога се интерпретира као текст. Из тог разлога описи графикона често делују као четири засебне целине, односно четири засебна краћа текста, у којима се тачно може препознати питање које је у задатку постављено. Ово такође наводи читаоца на закључак да текст није у потпуности кохерентан, будући да се ток мисли током читања више пута прекида и преноси на другу тему.

У текстовима студената на трећој години ситуација изгледа нешто другачије. Упркос чињеници да се и у радовима са треће године могу препознати исте или сличне номиналне фразе искоришћене у сврху структурисања текста, као и врло слични уводни делови, при њиховом поређењу не стиче се утисак да су поменуте фразе научене напамет и само 'убачене' на одговарајуће место у тексту. Разлог томе је превасходно чињеница да се јављају различите варијанте понуђених фраза, као и да се оне користе у различитим функцијама и контекстима. Такође, уколико је једна фраза искоришћена више пута у истом тексту, то је најчешће учињено уз мале измене у језичком материјалу, што у радовима са прве године није случај. Из овог разлога се већина текстова са треће године може без прекидања мисаоног тока пратити од почетка до краја и одаје утисак компактне, јединствене целине. 
Када се узму у обзир све поменуте примедбе, може се извући коначан закључак да су кохезивна средства у радовима на трећој години студија коришћена са више разумевања и на смисленији начин него што је то случај на првој години, те да радови на трећој години стога одају већи утисак кохерентности него радови са прве године.

\section{Ниво текстуалне компетенције студената према $3 E 0$}

При упису на Филолошки факултет у Београду, смер Немачки језик, књижевност, култура, од студената се очекује да поседују ниво језичке компетенције који одговара А2-Б1 нивоу ЗЕО (2003), док се на крају прве године студија очекује да су студенти достигли сигуран Б1 ниво. Након тога, на крају друге године очекује се да су студенти достигли ниво језичке компетенције Б2, док се по завршеној трећој години студија очекује да студенти достигну Ц1.1 ниво. На завршној години очекује се да студенти достигну ниво језичке компетенције Ц1.2. У предстојећем поглављу упоредићемо захтеве Катедре за германистику на првој и трећој години студија са резултатима добијеним анализом текстова са прве и треће године, са циљем да испитамо да ли су студенти испунили критеријуме за задате нивое језичке компетенције. У ту сврху било би погодно још једном се осврнути на закључке донесене на основу анализе кохезивних средстава у текстовима студената.

Резултати добијени уз помоћ ове анализе имплицирају да се језичка компетенција студената треће године, када је у питању критеријум кохерентности текста, налази на вишем нивоу, као и да је њихово схватање текста другачије (напредније). Може се приметити да студенти треће године текст не схватају само као „кохерентан след реченица“, већ да препознају и узимају у обзир чињеницу да текст има одређену комуникативну функцију коју треба да испуни. За студенте прве године текст, бар у оквиру анализираних писмених испита, још увек представља пуко одговарање на задата питања, уз коришћење уна- 
пред научених фраза, али без конкретног разумевања њихове основне комуникативне функције.

Уколико погледамо критеријуме кохерентности текста наведене у 3Е0, видећемо да се од студената на нивоу Б1, који би одговарао нивоу компетенције на првој години студија, очекује да „могу да повежу краће, једноставне и препознатљиве елементе у повезан говор“ (ЗЕО 2003: 130). У прилог овој тврдњи говори чињеница да студенти прве године више нагињу ка коришћењу простих реченица у односу на студенте треће године, због чега су у њиховим радовима конјунктори знатно заступљенији од субјунктора. Поред тога, у радовима са прве године може се приметити тенденција ка коришћењу израза који би припадали нижим нивоима језичке компетенције, вероватно из разлога што су студентима ови изрази већ познати, те стога представљају сигурне варијанте и претпостављају мању вероватноћу прављења грешака. Ову хипотезу поткрепљује мања заступљеност средстава супституције, парцијалних рекуренција и промене врсте речи, као и знатно већа заступљеност рекурентности истоветних језичких израза и веће ослањање на речи из истог лексичког поља.

Са друге стране, уколико погледамо критеријуме за први следећи виши ниво текстуалне језичке компетенције (почетни Б2 ниво), примећујемо да се од корисника очекује да „може да употребљава ограничен број артикулатора за повезивање језичког израза, иако се дешава да током неке дуже интервенције дође до 'празног хода"“ (ibid. 130). За многе радове са прве године студија ова тврдња не би била далеко од истине. Наиме, иако у овим радовима преовладавају једноставније језичке структуре, с правом се може рећи да су употребљена кохезивна средства разноврсна, премда не у тој мери као она употребљена у радовима са треће године студија. Такође се може констатовати да при покушају грађења сложених језичких структура или при употреби недовољно познатих израза код студената прве године студија неретко долази до прављења грешака, односно до 'празног хода'.

Када се све речено узме у обзир, долази се до закључка да су студенти на првој години на прелазу са Б1 на Б2 ниво текстуалних језичких компетенција. 
Када је реч о трећој години, претпостављени ниво знања је Ц1.1. У том смислу студенти би требало да буду способни да „произведу јасан, течан и добро структуриран текст, показујући контролисану употребу језичких средстава за структурисање и артикулацију" (ibid. 130). Као што смо претходно напоменули, добијени подаци говоре да студенти треће године студија располажу разноврсним језичким материјалом у погледу кохезивних средстава, као и да је присутност кохезивних елемената у текстовима релативно висока. Осим тога, поред саме употребе великог броја конектора, они су употребљени на смислен начин, тако да су текстови јасно структурисани од почетка до краја, што омогућава читаоцу да тему прати без већих ометања мисаоног тока. У складу са наведеним карактеристикама текстова студената са треће године студија, може се извести закључак да њихова текстуална језичка компетенција одговара очекиваном Ц1.1 нивоу.

\section{Закључак}

На основу резултата анализе писмених радова студената могу се извести следећи закључци:

- Када је у питању рекурентност језичког материјала, студенти прве године студија највише се ослањају на рекурентност истог језичког материјала, док су код студената треће године знатно заступљеније парцијалне рекуренције и промена врсте речи.

- Сва три вида супституције (синоними, антоними и хипероними) далеко су заступљенија у радовима студената треће године студија. На основу ова два фактора може се закључити да студенти треће године располажу ширим активним вокабуларом него студенти прве године, што њихову језичку компетенцију смешта на виши ниво од њихових млађих колега.

- У погледу проформи, у радовима са прве године заступљеније су једино личне заменице и присвојни и 
демонстративни детерминативи. Ова три средства захтевају нижу способност апстраховања и успостављања семантичких веза у тексту него демонстративне заменице и заменички прилози, којих има више у радовима студената са треће године.

- Релативне реченице такође су заступљеније на трећој години и чинећи комплексније и захтевније језичке структуре такође одговарају напредном нивоу језичке компетенције, док студенти прве године више нагињу грађењу низа простих реченица.

- Укупна заступљеност конектора већа је на трећој години студија, што је један од фактора који говоре о бољој повезаности текстова код старијих студената.

- Врсте речи употребљене у функцији конектора разноврсније су у радовима са треће године, што заједно са резултатима анализе рекурентности потврђује тврдњу да студенти треће године активно користе већи дијапазон језичких средстава у сврху постизања кохерентности.

- Док текстови студената прве године често делују испрекидано и једнолично, у радовима студената треће године примећује се боље јединство теме од почетка до краја текста.

- Сви наведени закључци недвосмислено сведоче о чињеници да се текстуална језичка компетенција студената на трећој години студија налази на знатно вишем нивоу него што је то случај код студената на првој години студија. Оно што је притом такође важно напоменути, јесте да су на утисак (не)кохерентности текста у великој мери утицале и граматичке грешке, које се знатно чешће јављају у радовима са прве године студија, а које понекад није ни могуће сасвим јасно разграничити од грешака у кохерентности. Имајући то у виду, сматрамо да би ова анализа кохезивних елемената могла бити употпуњена неком даљом анализом граматичких грешака у радовима студената, како би се добили прецизнији подаци о нивоу текстуалне језичке компетенције студената. 


\section{ЛИТЕРАТУРА}

Адамзик 2016: Adamzik, K. Textlinguistik: Grundlagen, Kontroversen, Perspektiven, 2., völlig neu bearbeitete, aktualisierte und erweiterte Neuauflage. Berlin/Boston: Walter de Gruyter GmbH.

Бринкер 1988: Brinker, K. Linguistische Textanalyse: eine Einführung in Grundbegriffe und Methoden, 2., durchgesehene und ergänzte Auflage. Berlin: Erich Schmidt Verlag.

Савет Европе 2001: Council of Europe. Common European framework of reference for languages: Learning, teaching, assessment. Cabridge: Press Syndicate of the University of Cambridge.

де Богранд и Дреслер 1981: de Beaugrande, R., Dressler W. Introduction to Text Linguistics. London/New York: Longman.

Ђуровић 2011: Đurović, A. Grundfragen der deutschen Syntax. Beograd: Filološki fakultet Univerziteta u Beogradu.

Халидеј, Рукаија 1976: Halliday, М. А. K., Ruqaiya H. Cohesion in English. London: Longman Group Ltd.

Линке и Нусбаумер 2000: Linke, A., Nussbaumer, M., Rekurrenz, in: Brinker et al. (Hrsg.) Text- und Gesprächslinguistik / Linguistics of Text and Conversation. Ein internationales Handbuch zeitgenössischer Forschung / An International Handbook of Contemporary Research 1. Halbbd. / Volume 1. Berlin/New York: Walter de Gruyter, 305-315.

Зандиг 2006: Sandig, В. Textlinguistik des Deutschen, 2., völlig neu bearbeitete und erweiterte Auflage. Berlin: Walter de Gruyter $\mathrm{GmbH} \& \mathrm{Co}$.

3EO 2003: Zajednički evropski referentni okvir za žive jezike: učenje, nastava, ocjenjivanje. Podgorica: Ministarstvo prosvjete i nauke.

Шварц-Фризел 2006: Schwarz-Frisel, M., Kohärenz versus Textsinn: Didaktische Facetten einer linguistischen Theorie der textuellen Kontinuität, in: Ziegler, A., Scherner M. (Hrsg.), Angewandte Textlinguistik: Perspektiven für den Deutsch- und Fremdsprachenunterricht. Tübingen: Narr (= Europäische Studien zur Textlinguistik 2), 63-75.

Шварц-Фризел и Констен 2014: Schwarz-Friesel, M., Consten, M. Einführung in die Textlinguistik. Darmstadt: WBG (Wissenschaftliche Buchgesellschaft) 


\section{Danijela Vranješ}

\section{TEXTKOHÄRENZ UND KOHÄSION IN SCHRIFTLICHEN PRÜFUNGEN VON STUDIERENDEN IM ERSTEN UND IM DRITTEN JAHR DES GERMANISTIKSTUDIUMS}

\section{Zusammenfassung}

Textkohärenz und -kohäsion sind als zentrale Begriffe in der Textlinguistik von ausschlaggebender Bedeutung, wenn es um die textuelle Sprachkompetenz geht. Anhand der im Rahmen dieser Untersuchung durchgeführten Analyse der Kohäsionselemente in schriftlichen Prüfungen von Studenten im ersten und im dritten Jahr des Germanistikstudiums an der Philologischen Fakultät in Belgrad konnte empirisch bewiesen werden, dass sich die textuelle Sprachkompetenz der Studenten im dritten Jahr auf einem deutlich höheren Niveau befindet als die der Studenten im ersten Jahr. Gemäß dem Gemeinsamen Europäischen Referenzrahmen für Sprachen entspricht die textuelle Sprachkompetenz der Studenten im ersten Jahr dem Niveau B1-B2, und die der Studenten im dritten Jahr dem Niveau C1.1.

Schlüsselwörter: Textkohärenz, Textkohäsion, textuelle Sprachkompetenz, Sprachkompetenz, Gemeinsamer Europäischer Referenzrahmen für Sprachen 